\title{
PENGELOLAAN KELAPA TERPADU ZERO WASTE DI DESA LEMBAH ASRI KECAMATAN WEDA SELATAN
}

\author{
Natal Basuki *1, Suhardi ${ }^{2}$, Suwandi S. Sangadji ${ }^{3}$ \\ 1,2,Program Studi Agribisnis Universitas Khairun \\ ${ }^{3}$ Program Studi Agribisnis Universitas Nuku Tidore \\ *e-mail: natal.basuki@unkhair.ac.id ${ }^{1}$, suhardiuim@ @mail.com ${ }_{2}^{2}$ \\ wandy@univ-nuku.ac.id ${ }^{3}$
}

\begin{abstract}
ABSTRAK
Potensi perkebunan kelapa yang dihasilkan oleh masyarakat Kecamatan Weda Selatan hanya memanfaatkan daging buah kelapa untuk pembuatan Kopra sehingga selain daging kelapa hanya menjadi sampah seperti Serabut, Tempurung dan ampas kelapa. Selain itu, potensi perkebunan kelapa tidak serta merta dapat meningkatkan taraf kesejahteraan petani yang terdapat di Kecamatan Weda Selatan, Kabupaten Halmahera Tengah sebab harga kopra mengalami fluktuasi harga yang akhirnya mengakibatkan kerugian yang dialami oleh petani kelapa. Penguasaan teknologi dan inovasi dalam mengelola buah kelapa menjadi produk turunan lain selain kopra tidak diketahui oleh petani sehingga tidak menambah niali guna produk yang memiliki nilai ekonomis yang tinggi dalam meningkatkan ekonomi keluarga petani. Kegiatan pengelolaan kelapa terpadu melaui PKM Kubermas Tematik ini bermitra dengan Badan Usaha Milik Desa (BUMDES) di Desa Lembah Asri, Kecamatan Weda Selatan, Kabupaten Halmahera Tengah. Melalui kegiatan PKM Kubermas akan dilakukan pelatihan pengolahan kelapa terpadu Zero Waste melalui pembuatan Virgin Coconut Oil (VCO), Minyak Kelapa Klasik, pembuatan pakan ternak dengan memanfaatkan ampas kelapa, dan pembuatan arang aktif. Pelaksanaan kegiatan PKM ini dimulai pada tanggal 22 Maret sampai dengan bulan Juli 2020. Tahapan pelaksanaan kegiatan dimulai dari Observasi Lapangan, Sosialisasi kegiatan, Pelatihan, Evaluasi, Publikasi dan Pelaporan. Hasil dari pelaksanaan kegiatan ini yaitu dapat meningkatnya pengetahuan dan kemampuan mitra khususnya dan umumnya mahasiswa kunermas dalam mengolah buah kelapa menjadi VCO, Minyak kelapa klasik, pakan ternak, dan arang aktif..
\end{abstract}

Kata kunci: VCO, Minyak kelapa klasik, Pakan ternak, Arang aktif. 


\section{PENDAHULUAN}

Gagasan Zero Waste Lifesyle (Gaya Hidup Tanpa Sampah) dinilai mampu memaksimalkan penekanan sampah rumah tangga, serta dipastikan mampu merubah pola perilaku masyarakat semula yang apatis menjadi kritis terhadap sampah terutama dengan sasaran ibu rumah tangga sebagai pelaku utama yang paling berperan dalam kehidupan keluarga (Komari, 2017 dalam Syarif A dan Zainuddin M, 2017).

Potensi perkebunan kelapa yang dihasilkan oleh masyarakat Kecamatan Weda Selatan hanya memanfaatkan daging buah kelapa sehingga selain daging kelapa hanya menjadi sampah seperti Serabut, Tempurung dan ampas kelapa. selain itu, potensi perkebunan kelapa tidak serta merta dapat meningkatkan taraf kesejahteraan petani yang terdapat di KecamatanWeda Selatan, Kabupaten Halmahera Tengah sebab harga kopra mengalami fluktuasi harga yang akhirnya mengakibatkan kerugian yang dialami oleh petani kelapa. Hal ini sejalan dengan harga kopra mengalami penurunan harga secara Nasional hingga Rp. 3.700 per Kilogram (MalutPost, 2019).

Dari uraian diatas maka, teridentifikasi maslah yang dapat diselesaikan selama pelaksanaan Kuliah Bersama Masyarakat (Kubermas) yang menjadi prioritas sesuai dengan RTRW Kabupaten Halmahera Tengah, utamanya di lokasi wilayah Kubermas

1. Murahnya harga kopra sehingga pendapatan petani kelapa mengalami penurunan.

2. Rendahnya pengetahuan petani kelapa dalam memanfaatkan buah kelapa menjadi produk lain selain kopra.

3. Rendahnya pengetahuan tentang cara pemasaran produk turunan dari kelapa.

Masaalah diatas dapat diselesaikan dengan adanya pelatihan dalam upaya peningkatan taraf kesejahteraan masyarakat Kecamatan Weda Selatan yang bekerja pada sektor perkebunan dengan komoditas kelapa sebagai potensi utama daerah Kepualaun dengan pendekatan pemberdayaan yang bertujuan meningkatkan harkat dan martabat serta kesejahterahaan lapisan masyarakat bahwa dengan segala keterbatasan yang dimiliki masyarakat, agar mampu melepaskan diri dari perangkap kemiskinan, kebodohan serta keterbelakangan, sehingga dapat menguatkan masingmasing individu masyarakat. (Siregar, Robert t., Hery P. Silitonga, Abd. R. Syamsuri, Abd. Halim, Dwi S. Haryani, Sutarmin, Suwandi S. Sangadji, et al. 2020) 
Upaya yang dilakukan melalui pelatihan kepada petani dengan memberikan pendampingan berupa pelatihan Pengelolaan Kelapa Terpadu Zero Waste untuk memberikan nilai guna kelapa menjadi produk yang bernilai tinggi secara ekonomis yang tentu dapat meningkatkan kesejahteraan petani serta mengurangi angka kemiskinan penduduk.

Tujuan dari kegiatan pelatihan Pegelolaan Kelapa Terpadu Zero Waste adalah memeberikan ilmu pengetahuan kepada petani kopra tentang tatacara membuat produk turunan dari buah kelapa yang tanpa menyisahkan residu.

Pemanfataan buah kelapa yang dimulai dari memanfaatkan daging kelapa menjadi Virgin Coconut Oil dan Minyak Kelapa Klasik, Tempurung atau cangkang kelapa dimanfaatkan untuk pembuatan Arang Aktif. serta sarabut kelapa dapat dimanfaatkan untuk bhan bakar pembuatan Arang Aktif juga dengan ampas dari daging kelapa yang telah diperas dapat dibuat fermentasi untuk pembuatan pakan ternak yang kaya protein.

\section{Analisis Situasi Mitra/ Wilayah Sasaran}

Kecamata Weda Selatan merupakan salah satu kecamatan yang terletak di Kabupaten Halmahera Tengah, Provinsi Maluku Utara. Kecamatan Weda Selatan memiliki luas Wilayah sebesar 237,42 $\mathrm{Km}^{2}$ atau 10,42 \% dari Luas Kabupaten Halmahera Tengah dengan jumlah penduduk sebesar 6,940 jiwa. Sebahagian besar masyarakat berprofesi sebagai petani. Sebagai kecamatan yang jaraknya jauh dari ibukota Kabupaten sehingga kehidupan sosial ekonomi yang tidak metropolis. Jumlah KK sebanyak 1.948 yang tergabung dari 8 (delapan) desa terdapat didalamnya yaitu Kluting Jaya, Wairoro Indah, Tilope, Sosowomo, Loleo, Sumber Sari, Lembah Asri, dan Air Salobar. (Kecamatan Weda dalam Angka, 2019).

Secara geografis Kecamatan Weda Selatan terletak diantara $0^{\circ} 15^{\prime}$ $0^{\circ} 16^{\prime}$ Lintang Utara dan $128^{\circ} 48^{\prime}-127^{\circ} 59^{\prime}$ Bujur Timur. Batas-batas Kecamatan Weda Selatan adalah sebagai berikut :

- Sebelah Utara dengan Kecamatan Weda

- Sebelah Selatan dengan Kabupaten Halmahera Selatan

- Sebelah Barat dengan Kota Tidore Kepulauan 
- Sebela Timur dengan Teluk Weda

Kecamata Weda Selatan merupakan salah satu kecamatan yang terletak di Kabupaten Halmahera Tengah, Provinsi Maluku Utara. Kecamatan Weda Selatan memeilki luas Wilayah sebesar $237,42 \mathrm{Km}^{2}$ atau $10,42 \%$ dari Luas Kabupaten Halmahera Tengah dengan jumlah penduduk sebesar 6,940 jiwa. Sebahagian besar masyarakat berprofesi sebagai petani. Sebagai kecamatan yang jaraknya jauh dari ibukota Kabupaten sehingga kehidupan sosial ekonomi yang tidak metropolis. Jumlah KK sebanyak 1.948 yang tergabung dari 8 (delapan) desa terdapat didalamnya yaitu Kluting Jaya, Wairoro Indah, Tilope, Sosowomo, Loleo, Sumber Sari, Lembah Asri, dan Air Salobar (Kecamatan Weda Selatan dalam Angka, 2019).

Berikut disajikan data rumahtangga perkebunan di setiap Kecamatan yang berada pada Kabupaten Halmahera Tengah sebagai berikut :

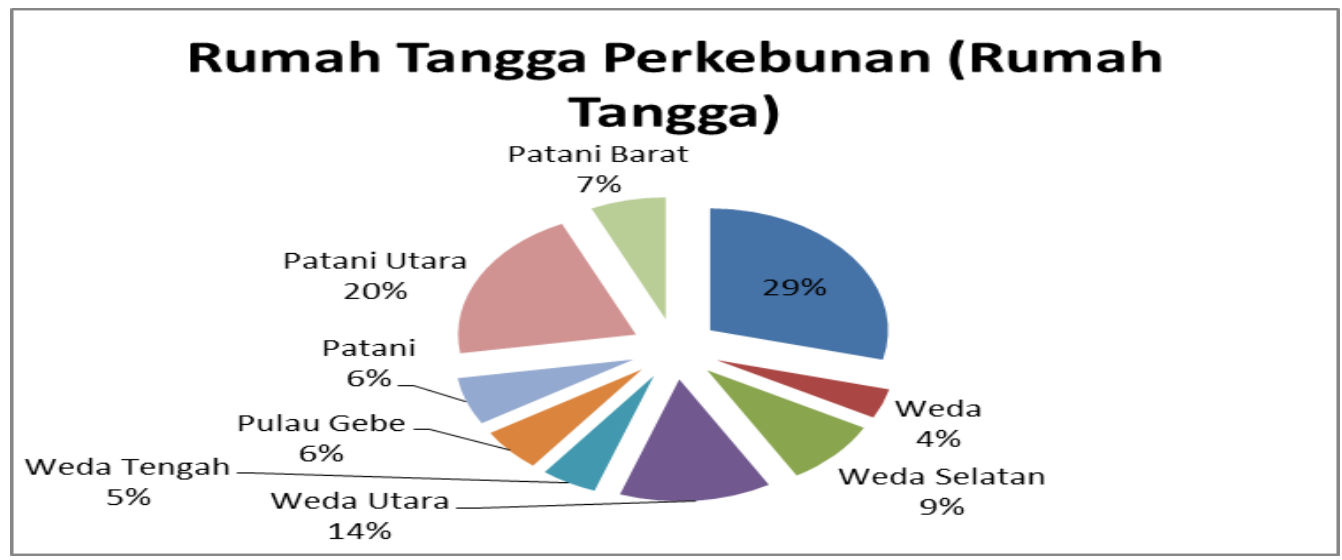

Gambar 1. Grafik tentang Rumah Tangga Perkebunan

Dari data diatas menunjukkan bahwa rumahtangga perkebunan yang terdapat pada Kecamatan Weda Selatan sebanyak $9 \%$ yang menggantungkan hidup pada sektor perkebunan. Kondisi ini menunjukkan bahwa kesejahteraan masyarakat Weda Selatan masih jauh dari harapan, sebab selain harga kopra yang murah, juga karena minimnya pengetahuan masyarakat tentang pengolahan buah kelapa menjadi produk turunan lainnya selain kopra.

Pendidikan merupakan salah satu kebutuhan yang menjadi barometer masyarakat yang berkualitas. Kualitas Sumberdaya Manusia menjadi sebuah modal 
dalam pembangunan. Dalam membentuk Sumberdaya yang berkualitas maka ditunjang dengan pendidikan yang berkualitas pula.

Kecamatan Weda Selatan terdapat sarana Sekolah diantaranya 8 Taman Kanak-kanak, 8 Sekolah Dasar, 3 SLTP, 1 MTs, 1 SMU, dan 1 SMK. Selain itu, ketersediaan sarana dan prasarana kesehatan juga turut serta membentuk kualitas SDM, utamanya aspek kesehatan jasmani dan rohani, dikecamatan Weda Selatan terdpat 1 Puskesmas, 6 Pustu, dan 8 posyandu, dan 1 praktik dokter.

Kondisi diatas menjadi potensi yang dimilki oleh masyarakat petani kelapa dalam memanfaatkan luas wilayah sebagai modal geografis dalam pengembangan budidaya kelapa dan dapat dimanfaatkan menjadi produk turunan lain yang memiliki nilai ekonomis tinggi selain dijadikan kopra. Potensi ini belum dimanfaatkan secara optmal sebagai penunjang peningkatan kesejahteraan petani.

Mitra kegiatan PKM adalah salah satu Badan Usaha Milik Desa (Bumdes) di Desa Lembah Asri, Kecamatan Weda Selatan, Kabupaten Halmahera Tengah yang anggotanya masih belum memiliki pengetahuan tentang pengolahan kelapa terpadu Zero Waste dalam upaya peningkatan kesejahteraan masyarakat melalui penambahan nilai tambah produk kelapa selain dibuat kopra.

\section{Permasalahan Mitra/ wilayah Sasaran}

Setelah dilakukan observasi maka ditemukan beberapa permasalahan yang dihadapi oleh masyarakat Kecamatan Weda Selatan adalah :

1. Murahnya harga kopra sehingga pendapatan petani kelapa mengalami penurunan.

2. Rendahnya pengetahuan petani kelapa dalam memanfaatkan buah kelapa menjadi produk lain selain kopra.

3. Rendahnya pengetahuan tentang cara pemasaran produk turunan dari kelapa.

\section{Solusi yang ditawarkan}

Berangkat dari munculnya permasalahan sebagaimana dimaksud di atas, maka penyelesaian masaalah disajikan pada tabel sebagai berikut :

Tabel 1. Permasalahan dan Solusi yang ditawarkan

\begin{tabular}{|c|c|c|}
\hline No & Permasalahan & Solusi Permasalahan \\
\hline 1. & $\begin{array}{l}\text { Murahnya harga kopra sehingga } \\
\text { pendapatan petani kelapa }\end{array}$ & $\begin{array}{l}\text { Memberikan sosialisasi tentang fluktuasi } \\
\text { harga kopra dan pengaruhnya terhadap }\end{array}$ \\
\hline
\end{tabular}




\begin{tabular}{|l|l|l|}
\hline & mengalami penurunan & pendapatan petani kelapa \\
\hline 2. & $\begin{array}{l}\text { Rendahnya pengetahuan petani } \\
\text { kelapa dalam memanfaatkan } \\
\text { buah kelapa menjadi produk lain } \\
\text { selain kopra }\end{array}$ & $\begin{array}{l}\text { Memberikan pelatihan pembuatan Virgin } \\
\text { Coconut Oil (VCO), Minyak Kelapa Klasik, } \\
\text { Arang Aktif, Pembuatan Pakan Ternak dari } \\
\text { ampas kelapa. }\end{array}$ \\
\hline 3. & $\begin{array}{l}\text { Rendahnya pengetahuan tentang } \\
\text { cara pemasaran produk turunan } \\
\text { dari kelapa }\end{array}$ & $\begin{array}{l}\text { Memberikan penyuluhan tentang cara } \\
\text { memasarkan produk melalui media online }\end{array}$ \\
\hline
\end{tabular}

Berdasarkan uraian masaalah dan solusi yang akan dilakukan terhadap masyarakat Kecamatan WedaSelatan sehingga kegiatan pemberdayaan masyarakat dapat berkelanjutan adalah dengan melibatkan mahasiswa sebagai agen of change sebagai peserta Kubermas dan masyarakat Weda Selatan sebagai masyarakat yang diberdayakan untuk memanfaatkan buah kelapa tidak hanya sekedar menjadi produk kopra, namun dapat membuat produk turunan lainnya berupa pembuatan Virgin Coconut Oil (VCO), Minyak Kelapa Klasik, Arang Aktif, dan Pembuatan pakan ternak dari ampas kelapa serta cara pemasaran produk melalui media online.

\section{METODE}

Pelaksanaan Pengabdian kepada Masyarakat di Kecamatan Weda Selatan direncanakan dilakukan dengan target peserta sekurang-kurangnya 10 orang mitra, yang dilakukan melalui penyuluhan, pelatihan dan pemberdayaan kepada masyarakat yaitu para petani kelapa, Pemerintahan Desa, dan warga 5 (lima) Desa yang terdapat di Kecamatan Weda Selatan. Kegiatan ini akan dilakukan oleh mahasiswa dengan didampingi oleh dosen. Mahasiswa yang dilibatkan dalam kegiatan ini yaitu mahasiswa Kubermas umumnya dan khusunya mahasiswa Fakultas Pertanian. Adapun tahapan kegiatan pengabdian yang dilaksanakan untuk mencapai hasil yang maksimal dan sesuai harapan dari tema Pengabdian kepada Masyarakat adalah:

Tabel 2. Tahapan Kegiatan Pengabdian Kepada Masyarakat

\begin{tabular}{|l|l|c|c|}
\hline No & \multicolumn{1}{|c|}{ Nama Program } & \multicolumn{1}{|c|}{$\begin{array}{c}\text { Volume } \\
\text { (jam) }\end{array}$} & Ket \\
\hline 1. & $\begin{array}{l}\text { Memberikan sosialisasi tentang fluktuasi harga } \\
\text { kopra dan pengaruhnya terhadap pendapatan petani } \\
\text { kelapa }\end{array}$ & 2 JP & \\
\hline 2. & Memberikan pelatihan pembuatan Virgin Coconut & & \\
\hline
\end{tabular}




\begin{tabular}{|c|l|c|c|}
\hline & $\begin{array}{l}\text { Oil (VCO), Minyak Kelapa Klasik, Arang Aktif, } \\
\text { Pembuatan Pakan Ternak dari ampas kelapa. }\end{array}$ & $48 \mathrm{JP}$ & 5 kali lapangan \\
\hline 3. & $\begin{array}{l}\text { Memberikan penyuluhan tentang cara memasarkan } \\
\text { produk melalui media online }\end{array}$ & $2 \mathrm{JP}$ & \\
\hline
\end{tabular}

\section{HASIL DAN PEMBAHASAN}

Dalam pelaksanaan kegiatan Pengabdian Kepada Masyarakat (PKM) Kubermas Tematik di Desa Lembah Asri Kec. Weda Selatan dilakukan dengan identifikasi permasalahan mendasar yang dihadapi oleh Mitra dimana pendapatan mitra mengalami fluktuasi sebagaimana fluktuatifnya harga kopra sehingga dilakukan sosialisasi pengetahuan tentang fluktuasi harga kopra dan pengaruhnya terhadap pendapatan petani. Nilai edukasi dari kegiatan ini menghasilkan semakin bertambahnya pengetahuan mitra tentang fluktuasi harga dan pengaruhnya terhadap mitra sehingga menjadi bahan pembanding dalam pengelolaan buah kelapa dalam pendekatan analisis kelayakan usaha.

Selain hal diatas, Rendahnya pengetahuan petani kelapa dalam memanfaatkan buah kelapa menjadi produk lain selain kopra mengakibatkan tidak adanya inovasi produk yang memiliki kebaharuan produk dengan nilai ekonomis harga produk yang lebih tinggi. Olehnya itu, mitra diberikan pelatihan pembuatan Virgin Coconut Oil (VCO), Minyak Kelapa Klasik, Arang Aktif, Pembuatan Pakan Ternak dari ampas kelapa.

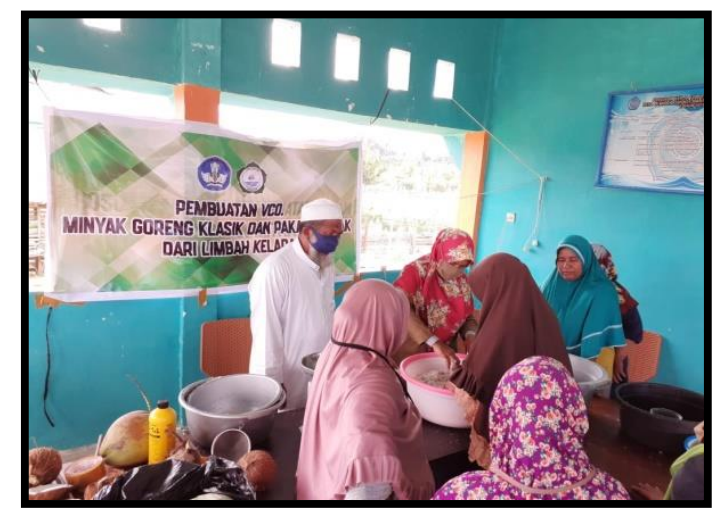

Gambar 2. (a) Pelatihan pembuatan Virgin Coconut Oil (VCO), Minyak Kelapa Klasik, Arang Aktif, Pembuatan Pakan Ternak dari ampas kelapa

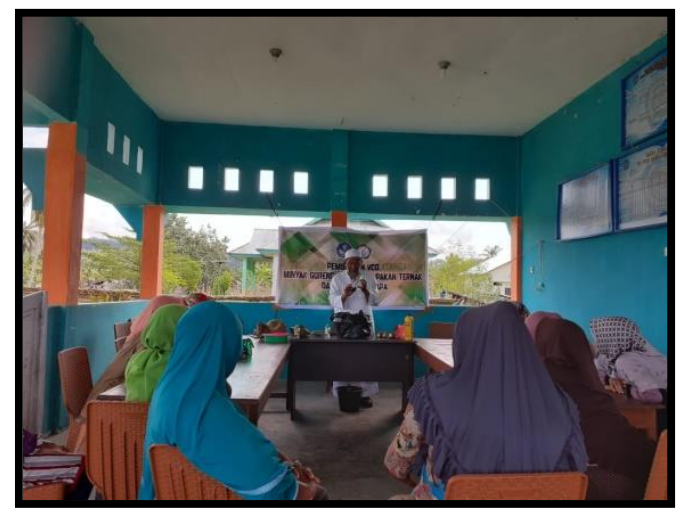

(b) Sosialisasi tentang fluktuasi harga kopra dan pengaruhnya terhadap pendapatan petani kelapa 
Dari gambar diatas, terlihat bahwa mitra sangat antusias dalam mengikuti kegiatan pengabdian kepada masyarakat, baik itu pelatihan pembuatan Virgin Coconut Oil (VCO), Minyak Kelapa Klasik, Arang Aktif, Pembuatan Pakan Ternak dari ampas kelapa maupun Sosialisasi tentang fluktuasi harga kopra dan pengaruhnya terhadap pendapatan petani kelapa.

Rendahnya pengetahuan tentang cara pemasaran produk turunan dari kelapa juga berdampak pada rendahnya pendapatan petani karena keputusan konsumen untuk membeli produk turunan yang dimaksud juga terbilang rendah. Hal ini sejalan dengan hasil penelitian Sangadji, S., Suhardi, S., \& Ali, C. P. M. (2019) dan Sangadji, S. S. (2016) yang mengemukakan bahwa tingginya keputusan pembelian produk pertanian dipengaruhi oleh faktor-faktor bauran pemasaran. Dengan demikian maka dalam program pengabdian kepada masyarakat (PKM) ini juga dilakukan penyuluhan tentang cara memasarkan produk melalui media online guna memasarkan produk ditengah mewabahnya virus COVID 19. Menurut Karniyati, A., Suhardi, S., \& Sangadji, S. S. (2019) dan Ngabalin, L. S., Sangadji, S. S., \& Suhardi, S. (2019) kegiatan penyuluhan semestinya menggunakan komunikasi yang efektif dan dapat menununjang keberhasilan kegiatan penyuluhan itu sendiri. Selain itu, yang lebih penting lagi adalah mengubah sikap dan perilaku masyarakat pertanian agar mereka tahu dan mau menerapkan informasi atau anjuran yang disampaikan oleh Penyuluh.

\section{KESIMPULAN}

Kesimpulan dari pengabdian masayrakat dengan judul pengelolaan kelapa terpadu zero waste di Desa Lembah Asri Kecamatan Weda Selatan adalah seabgai berikut:

Adanya peningkatan pengetahuan tentang fluktuasi harga kopra dan pengaruhnya terhadap pendapatan petani kelapa.Peningkatan pengetahuan peserta pelatihan dalam pembuatan Virgin Coconut Oil (VCO), Minyak Kelapa Klasik, Arang Aktif, Pembuatan Pakan Ternak dari ampas kelapa.Peningkatan pengetahuan tentang cara memasarkan produk melalui media online.Kendala dalam pelaksanaan pengabdian adalah adanya covid 19 sehingga dilakukan Lock down oleh Pemda 
Halmahera Tengah sehingga kegiatan mengalami penundaan namun dapat terselesaikan sesuai rencana.Perlu adanya pendampingan yang kontinu dalam upaya peningkatan usaha.

\section{DAFTAR PUSTAKA}

Kammaruddin, B. (2019). Harga Kopra di Morotai Rp. 3.700. (Online). Tersedia : http://news.malutpost.co.id [22/10/2019].

Karniyati, A., Suhardi, S., \& Sangadji, S. S. (2019). PeranPenyuluhPertanian dalam Pemberdayaan Kelompok Tani Di Desa Ampera Kecamatan Oba Utara Kota Tidore Kepulauan. Aksara Public, 3(2), 99-108.

Kecamatan Weda Selatan dalam Angka 2019. Badan Pusat Statistik Kabupaten Halmahera Tengah

Ngabalin, L. S., Sangadji, S. S., \& Suhardi, S. (2019). PengaruhPenyuluhanPertanian Terhadap Efektivitas Kelompok Tani Jaya di Desa Danar Kecamatan KeiKecil Timur Selatan Kabupaten Maluku Tenggara. Aksara Public, 3(2), 71-84.

Rahmat, D.C. 2019. Kecamatan Patani dalam Angka. BPS Kabupaten Halmahera Tengah. CV, Tarataro.

Silitonga, H. P., Syamsuri, A. R., Halim, A., Haryani, D. S., Sangadji, S. S., \& Samad, A. (2020). PEMASARAN" Hasil pemikiran dari Para Dosen Berbagai Perguruan Tinggi di Indonesia (Book Chapter-)" (No. h7p6v). Center for Open Science.

Sangadji, S., Suhardi, S., \& Ali, C. P. M. (2019). PengaruhBauranPemasaran terhadap Keputusan Pembelian Sagu Rasa pada Gabungan Kelompok Tani Tagafura di Kelurahan Jaya Kota Tidore Kepulauan. Optimal: Jurnal Ekonomi dan Kewirausahaan, 13(2), 142-157.

Sangadji, S. S. (2016). Analisis Pengambilan Keputusan Konsumen terhadap Pembelian Jus Belimbing Winner PerkasaIndonesia UnggulDi Kota Depok (Doctoral dissertation, Universitas Mecu Buana Jakarta).

Syarif, A dan Zainuddin M. (2017). KajianPeran PerempuanDalam Usahatani Sayuran yang Berlandaskan Zero Waste di Kecamatan Bissappu Kabupaten Bantaeng [Online]. Jurnal Galung Tropika. Vol 6 (2), hal 114123. Tersedia https://jurnalpertanianumpar.com/index.php/jgt/article/view/232 